Erratum

\title{
Erratum: Fabrication of Chitin/Poly(butylene succinate)/Chondroitin Sulfate Nanoparticles Ternary Composite Hydrogel Scaffold for Skin Tissue Engineering. Polymers, 2014, 6, 2974-2984
}

S. Deepthi ${ }^{1}$, C. V. Sidhy Viha ${ }^{1}$, Chaochai Thitirat ${ }^{2}$, Tetsuya Furuike ${ }^{2}$, Hiroshi Tamura ${ }^{2, *}$ and Rangasamy Jayakumar 1,2,*iD

1 Amrita Centre for Nanosciences and Molecular Medicine, Amrita Institute of Medical Sciences and Research Centre, Amrita Vishwa Vidyapeetham University, Kochi-682 041, India; deepthisankar@aims.amrita.edu (S.D.); sidhyvihacv@aims.amrita.edu (C.V.S.V.)

2 Faculty of Chemistry, Materials and Bioengineering, Kansai University, Osaka 564-8680, Japan; thitirat777@hotmail.com (C.T.); furuike@kansai-u.ac.jp (T.F.)

Received: 22 February 2019; Accepted: 8 March 2019; Published: 11 March 2019

The authors wish to make a change to the published paper [1]. In the original manuscript, Figure $6 \mathrm{~B}$ was inadvertently the same as Figure 6E. The corrected Figure 6 is presented below.
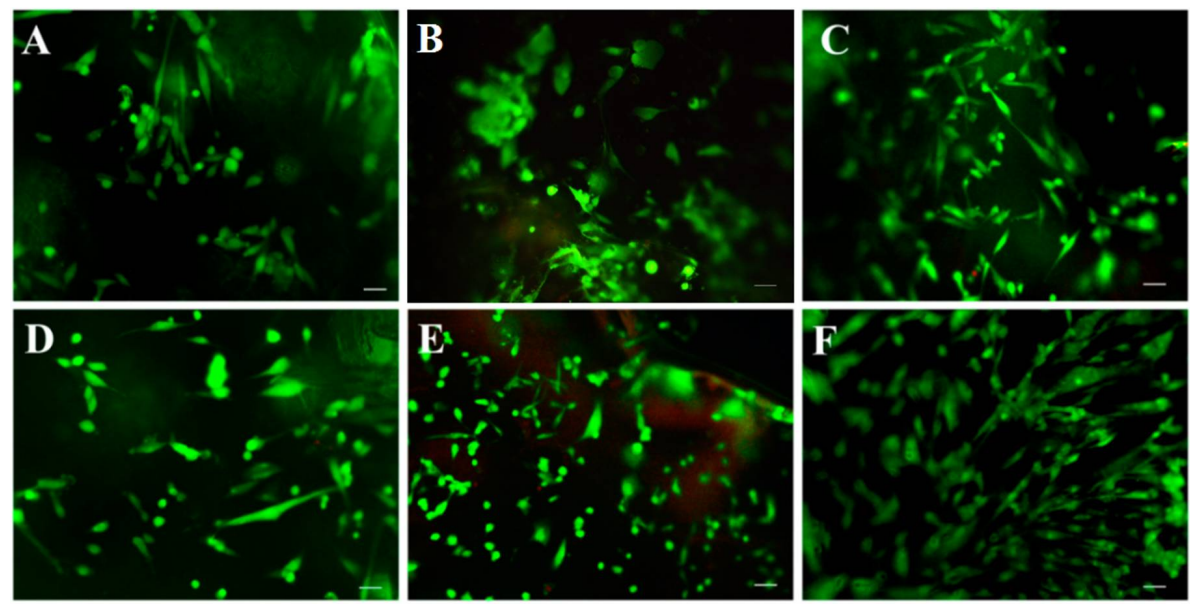

Figure 6. Live-dead assay of HDFs on (A,D) Chitin, (B,E) Chitin/PBS, (C,F) Chitin/PBS/CSnps after $24 \mathrm{~h}(\mathbf{A}-\mathbf{C})$, and $48 \mathrm{~h}(\mathbf{D}-\mathbf{F})$. Scale bar denotes $50 \mu \mathrm{m}$.

The authors apologize for any inconvenience caused. The change does not affect the scientific results. The manuscript will be updated, and the original will remain online on the article webpage https:/ / www.mdpi.com/2073-4360/6/12/2974.

\section{Reference}

1. Deepthi, S.; Viha, C.V.S.; Thitirat, C.; Furuike, T.; Tamura, H.; Jayakumar, R. Fabrication of Chitin/Poly(butylene succinate)/Chondroitin Sulfate Nanoparticles Ternary Composite Hydrogel Scaffold for Skin Tissue Engineering. Polymers 2014, 6, 2974-2984. [CrossRef]

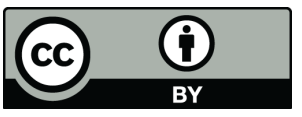

(C) 2019 by the authors. Licensee MDPI, Basel, Switzerland. This article is an open access article distributed under the terms and conditions of the Creative Commons Attribution (CC BY) license (http:/ / creativecommons.org/licenses/by/4.0/). 